\title{
PENINGKATAN KELAS EKONOMI MASYARAKAT MELALUI PENGOLAHAN “MENYOK GENDURWO" PASCA PANEN DI DESA TRENGGULUNAN, KECAMATAN NGASEM, KABUPATEN BOJONEGORO
}

\author{
Anif Muchlashin ${ }^{1)}$ \\ 1)Program Pascasarjana Departemen Pembangunan Sosial dan Kesejahteraan, Fisipol, UGM, Yogyakarta, Indonesia \\ Corresponding author: Anif Muchlashin \\ E-mail : anif.m@mail.ugm.ac.id
}

Diterima 12 November 2020, Direvisi 16 November 2020, Disetujui 16 November 2020

\begin{abstract}
ABSTRAK
Penelitian ini terfokus membahas tentang llegal logging pohon jati yang terjadi di Desa Trenggulungan. Masalah ini menjadi serius karena hutan rakyat yang menjadi tujuan nasional justru menjadi kepentingan pribadi petani. Melalui hasil tulisan jurnal ini peneliti telah menelaah realitas yang terjadi. Ekonomi menjadi salah satunya yakni terbatasnya sumber daya alam dan minimnya pengetahuan masyarakat yang menjadi fokus permasalahan. Ketela pohon dan jagung adalah komoditas yang unggul di Desa Trenggulunan, peneliti telah melakukan pendampingan untuk mengolah ketela pohon untuk meningkatkan nilai dari ketela pohon yang sebelumnya hanya menjadi pakan ternak, karena menyok gendurwo ini mengandung sianida dan ketika dikonsumsi langsung akan mengakibatkan diare ataupun kepusingan, sehingga perlu diolah dengan cara tertentu. Peneliti menggunakan metodologi PAR (Participatory Action Research) sebagai metode penelitian. Dengan pendekatan yang sudah dilakukan, dapat diketahui permasalahan di desa Trenggulunan yakni rendahnya pendapatan masyarakat karena masyarakat Trenggulunan selalu menjual hasil taninya langsung kepada tengkulak, dimana tengkulak yang menentukan harga jualnya. Oleh karena itu, dibutuhkan suatu program untuk meningkatkan pendapatan masyarakat yaitu dengan mengolah salah satu hasil tani yang berupa Ketela Pohon menjadi Kerupuk Singkong. Kerupuk Singkong ini yang kemudian diberi nama Merana.
\end{abstract}

Kata kunci: pasca panen; peningkatan ekonomi; illegal logging; ketela pohon.

\begin{abstract}
This research focuses on discussing illegal logging of teak trees that occur in Trenggulungan Village. This problem becomes serious because community forests, which are the national goals, are in the personal interests of farmers. Through the results of this journal's writing, the researcher has examined the reality that occurs. Economy is one of them, namely the limited natural resources and the lack of public knowledge which is the focus of the problem. Cassava and maize are superior commodities in Trenggulunan Village, researchers have provided assistance to process cassava to increase the value of cassava which was previously only used as animal feed, because gendurwo contains cyanide and when consumed directly it will cause diarrhea or dizziness, so that needs to be processed in a certain way. Researchers used the PAR (Participatory Action Research) methodology as a research method. With the approach that has been taken, it can be seen that the problem in Trenggulunan village is the low income of the community because the Trenggulunan people always sell their produce directly to middlemen, where the middlemen determine the selling price. Therefore, a program is needed to increase community income by processing one of the agricultural products in the form of cassava into cassava crackers. These cassava crackers were later given the name Merana.
\end{abstract}

Keywords: post harvest; economic improvement; illegal logging; cassava.

\section{PENDAHULUAN}

Mayoritas pekerjaan dan sumber ekonomi masyarakat di desa Trenggulunan, kecamatan Ngasem yaitu sebagai petani, dan bekerja di hutan sebagai pencari kayu bakar. Kondisi ini di pengaruhi oleh kondisi alam yang dikelilingi oleh sawah, tegal dan juga hutan. Sudah jelas bahwa rata-rata masyarakat di desa trunggulunan adalah berprofesi sebagai petani. Secara ekonomi, masyarakat Trenggulunan rata-rata memiliki perekonomian menengah ke bawah. Seluruh hasil tani dijual kepada tengkulak. Selain ke tengkulak, hasil tani seperti kacang tanah, dan ketela pohon dijual ke pasar, padi dijual ke masyarakat sekitar, dan kacang hijau dijual kepada agen. Tengkulak termasuk kelompok yang memiliki pengaruh kuat dengan petani desa 
Trenggulunan. Mereka adalah kelompok paling utama yang menjadi sasaran petani dalam menjual hasil taninya. Petani menjual hasil taninya dengan tidak menentukan harga jualnya. Tengkulak yang menentukan harga dari hasil tani tersebut. Dengan kata lain, petani tidak mendapatkan keuntungan yang layak dari produk yang dihasilkan dan keuntungan maksimal justru diperoleh dari tengkulak yang memanfaatkan rendahnya daya tawar petani dalam menentukan harga. Selain itu, para petani lebih senang menjual hasil taninya ke tengkulak karena hasil taninya lebih cepat terjual. Hal ini lah yang berdampak pada rendahnya pendapatan masyarakat.

Beberapa faktor yang menghambat perkembangan desa untuk maju adalah kurang pemahaman masyarakat Trenggulunan untuk menjadikan hasil panennya sebagai sesuatu yang bermanfaat bagi perekonomian mereka selain itu penjualan berbagai hasil tanaman kepada tengkulak dengan harga yang cukup miris juga menjadi pendorong kurang berkembangnya perekonomian masyarakat desa Trenggulunan. Melihat kebiasaan masyarakat Trenggulunan yang selalu menjual hasil taninya kepada tengkulak secara langsung, maka perlu adanya pengolahan hasil panen secara kreatif, sehingga nilai jual dari hasil panen tersebut meningkat. Kreatif menurut kamus besar bahasa Indonesia adalah (1) memiliki daya cipta; memiliki kemampuan untuk menciptakan (2) bersifat (mengandung) daya Sedangkan kreativitas diartikan sebagai proses memproduksi sesuatu yang orisnil dan bernilai (Alwi, 2002:23).

Dari pengertian diatas, kondisi masyarakat desa Trenggulunan termasuk belum dikatakan kreatif karena masyarakat desa Trenggulunan belum memiliki kemampuan untuk menciptakan sebuah perubahan yang signifikan untuk meningkatkan perekonomiannya. Terutama pemanfaatan dari hasil pertanian yaitu Ketela Pohon. Biasanya hasil panen ketela pohon yang ada hanya dijadikan sebagai makan ternak dan selebihnya hanya dijemur didepan rumah untuk dijadikan "Gaplek". Oleh karena itu, untuk meningkatkan pendapatan masyarakat, perlu adanya olahan Ketela Pohon yang dapat di jual di pasaran dengan harga yang terjangkau. Dengan adanya permasalahan tersebut peneliti bersama masyarakat berinisiatif untuk mengolah Ketela pohon menjadi Kerupuk singkong.

Alasan utama pengolahan kerupuk singkong adalah untuk meneruskan kembali rumah produksi yang sempat berjaya namun sekarang tumbang itu selain itu peneliti juga ingin membantu mengangkat perekonomian masyarakat desa Trenggulunan kearah yang lebih baik. Meskipun membutuhkan waktu yang cukup lama dengan alat yang masih sederhana namun setidaknya perekonomian masyarakat bisa terangkat dengan mengolah ketela pohon menjadi kerupuk singkong yang memiliki daya jual tinggi dipasar global. Pemahaman akan masalah untuk dapat mengubah keadaan social illfare menuju social welfare dengan cara memahami realita dan berkomitmen untuk memcahkannya (Soetomo, 2018:6).

Tulisan ini akan menjelaskan gambaran pengelolaan Ketela Pohon secara kreatif menjadi kerupuk singkong di desa Trenggulunan, kecamatan Ngasem, kabupaten Bojonegoro. Dengan harapan dapat meningkatkan kreativitas dan pendapatan perekonomian masyarakat setempat. Menurut Soetomo (2014:33) pemahaman masyarakat atas permasalahan dalam bentuk identitikasi sangat penting agar mereka memahami permasalahan yang sedang mereka hadapi dan bagaimana cara mengatasinya. Hal ini serupa dengan apa yang dikatakan oleh James Midgley $(2013$ : 17) yang menyatakan bahwa proses pembangunan adalah proses yang terencana menuju kesejahteraan masyarakat. Harapannya dengan pemahaman akan permasalahan yang masyarakat Desa Trenggulunan akan menciptakan peningkatan kesejahteraan yang dapat dinikmati oleh masyarakat.

\section{METODE}

Penelitian ini menggunakan metode Participatory Action Research (PAR). PAR menurut Afandi (2014) diartikan sebuah istilah yang memuat seperangkat asumsi yang mendasari paradigma baru ilmu pengetahuan dan bertentangan dengan paradigma pengetahuan tradisional kuno. Asumsi-asumsi baru tersebut menggaris bawahi arti penting proses sosial dan kolektif dalam mencapai kesimpulan-kesimpulan mengenai "apa kasus yang sedang terjadi" dan "apa implikasi perubahannya" yang dipandang berguna oleh orang-orang yang berada pada situasi problematik, dalam mengantarkan untuk melakukan penelitian awal. Lebih lanjut lagi Afandi (2014) menjelaskan PAR terdiri dari tiga kata yaitu partisipatory atau dalam bahasa Indonesia partisipasi yang artinya peran serta, pengambilan bagian, atau keikutsertaan. Kemudian action yang artinya gerakan atau tindakan, dan research atau riset artinya penelitian atau penyelidikan.

Proses riset pendampingan dengan menggunakan metode PAR perlu adanya strategi pendampingan yang harus dilakukan. Sebagai landasan dalam cara kerja PAR adalah gagasan-gagasan yang datang dari rakyat, 
dengan melakukan gerakan. Strategi pendampingan ini merupakan proses yang dilakukan sebagai pendekatan sehingga proses riset, pembelajaran dan pemecahan teknis dari problem sosial komunitas dapat dilakukan secara terencana, terprogram dan terlaksana bersama masyarakat. Strategi yang dilakukan dalam pemberdayaan di lapangan. Langkahlangkahnya sebagai berikut.

\section{a. Pemetaan Awa}

Pemetaan awal sebagai alat untuk memetakan potensi yang dimiliki Desa Trenggulunan dan masalah apa yang sedang dihadapi dengan menggunakan peta. Peta awal juga memetakan untuk mencakup potensi pertanian yang dimiliki.

\section{b. Penetuan Agenda Riset untuk Perubahan Sosial}

Bersama masyarakat sekitar, peneliti mengagendakan program riset melalui teknik Partisipatory Rural Appraisal $(P R A)$. untuk memahami waktu untuk menentukan waktu yang tepat untuk membangun Desa Trenggulunan secara partisipatif.

\section{c. Pemetaan Partisipatif}

Bersama masyarakat Desa Trenggulunan peneliti melakukan pemetaan wilayah, melihat persoalan yang dialami masyarakat. Pemetaan partisipatif sebagai bagian emansipatori mencari data secara langsung bersama masyarakat.

\section{d. Merumuskan Masalah Kemanusiaan} Bersama masyarakat akan merumuskan masalah mendasar hajat hidup kemanusiaan yang dialaminya. Sebagaimana dalam pendampingan ini fokus rumusan kemanusiaanya adalah membangun kesadaran masnusia dalam sadar akan potesi dan masalah.

\section{e. Menyusun Strategi Gerakan}

Peneliti dan masyarakat menyusun strategi gerakan untuk memecahkan problem kemanusiaan yang telah dirumuskan. Fokusnya adalah mengenalkan potensi dan menyadarkan masalah yang ada untuk dipecahkan secara bersamasama.

\section{f. Pengorganisasian Masyarakat}

Peneliti bersama masyarakat membangun pranata-pranata sosial. Dalam hal ini adalah memaksimalkan potensi pertanian untuk meningkatkan ekonomi masyarakat. Selain itu juga perlu membentuk kelompok melalui institusi sosial yang sudah terbentuk untuk mempermudah pengorganisasian masyarakat.

\section{g. Melancarkan Aksi Perubahan}

Peneliti bekerja bersama-sama dengan masyarakat untuk membuat aksi menuju perubahan yang diinginkan.

h. Refleksi

Peneliti bersama masyarakat
dampingan merumuskan teoritisasi
perubahan sosial. Berdasarkan atas hasil
riset, proses pembelajaran masyarakat dan
program-program aksi yang sudah
terlaksana.

\section{i. Meluaskan Sekala Gerakan Dukungan}

Setelah berhasil kemudian peneliti mencoba mempublikasikan hasil dari kegiatan ini untuk memperluas gerakan agar dapat diadopsi oleh peneliti lainnya untuk dapat diadopsi dan diterapkan ke tempat lainnya.

Masalah utama yang di hadapi masyarakat desa Trenggulunan adalah rendahnya pendapatan masyarakat. Dari diskusi bersama masyarakat ditemukan bahwa rendahnya pendapatan masyarakat disebabkan oleh rendahnya harga jual hasil pertanian dan belum maksimalnya pengelahan ketela pohon menjadi kerupuk yang memiliki daya jual tinggi.

Dalam rangka mengetahui dan memahami problem yang ada pada masyarakat Desa Trenggulunan, Peneliti melakukan FGD dengan seluruh lapisan masyarakat, selain bertujuan untuk mengetahui dan memahami problemproblem yang ada pada msayarakat juga bertujuan untuk mendapatkan kesepakatan mengenai fokus penelitian. Peneliti mengetahui bahwa mayoritas mata pencaharian masyarakat Trenggulunan adalah bertani. Selain itu kami juga melihat banyaknya Ketela pohon yang di jemur dihalaman rumah hanya untuk dijadikan gaplek dan ada yang dijadikan sebagai makanan ternak. Berawal dari hal tersebut, Peneliti dan masyarakat berinisiatif untuk mengolah Ketela pohon menjadi kerupuk singkong yang diharapkan dapat meningkatkan pendapatan masyarakat desa.

\section{HASIL DAN PEMBAHASAN}

Desa Trenggulunan merupakan Desa yang terletak di kecamatan Ngasem, kabupaten Bojonegoro. Berdasarkan data dari RPJMDes (Rencana Jangka Panjang dan Menengah Desa) luas wilayah Desa Trenggulunan 
menurut penggunaannya luas pemukiman 79 ha, luas persawahan 134 ha, luas pekuburan 4 ha, luas pekarangan ha, luas perkantoran 0,005 ha, dan luas prasarana umum lainnya 5 ha. Kualifikasi tanah sawah di Desa Trenggulunan adalah sawah tadah hujan 134 ha. Sedangkan penggunaan tanah kering di Desa Trenggulunan adalah untuk ladang $30 \mathrm{ha}$, untuk pemukiman 65,9 ha dan untuk pekarangan 30 ha. Penggunaan tanah fasilitas umum digunakan untuk tanah bengkok 18,4 ha, untuk lapangan sepak bola 0,65 ha, untuk lapangan bola volley 0,006 ha, perkantoran pemerintah 0,005 ha, tempat pemakaman umum 4 ha, tempat pertokoan 0,003 ha, jalan 5 ha.

Jarak Desa Trenggulunan mempunyai posisi jarak ke ibu kecamatan $5 \mathrm{~km}$. Lama jarak tempuh ke ibu kota kecamatan 0,25 jam dan didukung keberadaan kendaraan umum, jarak ke ibu kota kabupaten $35 \mathrm{~km}$, lama jarak tempuh ke ibu kota kabupaten 1 jam juga didukung keberadaan kendaraan umum, jarak ke ibu kota propinsi $140 \mathrm{~km}$ dengan lama jarak tempuh 4 jam dan didukung keberadaan kendaraan umum yang rutin dan berjumlah banyak.

Tabel 1. Tabel Wilayah Desa Trenggulunan

\begin{tabular}{cc}
\hline Nama Dusun & RT \\
\hline Dusun Krajan & RT 1-6 \\
\hline Dusun Blimbing & RT 7, 8, 9, 10, 11 \\
& dan 14 \\
\hline Dusun Ringin Anom & RT 12 dan 13 \\
\hline
\end{tabular}

Secara batas wilayah, Wilayah Desa Trenggulunan Kecamatan Ngasem Kabupaten Bojonegoro dengan dengan batas wilayah : Utara : Desa Kolong Timur : Desa Butoh Selatan : Desa Setren Barat: Desa Setren Terbagi menjadi : 1.3 (tiga) dusun 2. 3 (tiga) Rukun Warga 3. 14 (empat belas) Rukun Tetangga.

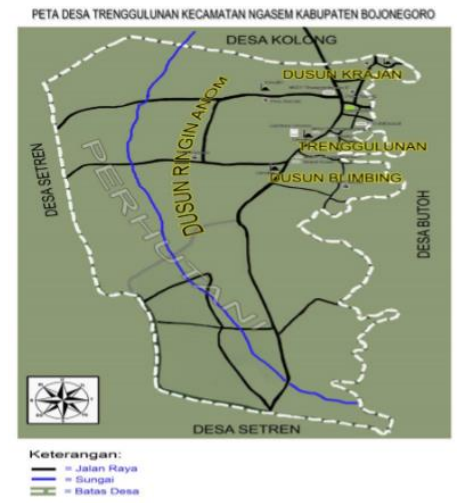

Gambar 1 : Peta Desa Trenggulunan

Kondisi Demografi Berdasarkan data hasil pemutahiran profil desa bulan Juli s/d Desember 2014, jumlah penduduk tahun lalu sebesar 2.921 jiwa dan tahun ini ada 2.947. Dengan demikian prosentase pertambahan penduduk Desa Trenggulunan 0,88 \%. Jumlah keluarga tahun ini ada $847 \mathrm{KK}$, sedangkan tahun yang lalu ada $832 \mathrm{KK}$ atau ada kenaikan $1,77 \%$. Prosentase perkembangan keluarga jauh lebih tinggi dari pada prosentase perkembangan penduduk, karena ajuan $\mathrm{KK}$ baru meningkat dengan berbagai motivasi. Salah satu motivasinya adalah berhubungan dengan dana bantuan BLT, LPG, dll. Kualitas kesejahteraan keluarga masyarakat Trenggulunan pada tahun 2014 menunjukan $377 \mathrm{KK}$ atau $44,52 \%$ yang berada di strata pra sejahtera, 32,24 \% berposisi sejahtera I dengan $273 \mathrm{KK}, 15,93 \%$ berposisi sejahtra II dengan $135 \mathrm{KK}, 6,13 \%$ berposisi sejahtera III dengan $52 \mathrm{KK}$, dan hanya 1,18\% yang sudah berposisi keluarga sejahtera III plus dengan $10 \mathrm{KK}$. Administrasi Pemerintahan Desa, jumlah penduduk yang tercatat secara administrasi, jumlah total 2.947 jiwa. Dengan rincian penduduk berjenis kelamin laki-laki, berjumlah 1.475 jiwa, sedangkan berjenis kelamin perempuan berjumlah 1.472 jiwa. Data tersebut berdasarkan hasil pemutahiran profil desa yang dilakukan oleh ketua RT pada bulan Juli 2014.

Tabel 2. Jumlah Penduduk Desa Trenggulunan

\begin{tabular}{llll}
\hline No & $\begin{array}{c}\text { Jenis } \\
\text { Kelamin }\end{array}$ & Jumlah & Prosentase \\
\hline 1 & Laki-Laki & 1475 & $50.05 \%$ \\
\hline 2 & Perempuan & 1472 & $49,95 \%$ \\
\hline Jumlah & 2947 & $100 \%$ \\
\hline
\end{tabular}

Dari hasil pendataan RT dibandingkan dengan data yang ada di administrasi desa, terdapat selisih yang tidak tercatat. Hal ini mendorong pemerintah desa untuk memperbaiki sistem administrasinya dan melakukan cek ulang terhadap penyebab terjadinya selisih data penduduk tersebut. Sampai saat didapatkan kesimpulan sementara bahwa terjadinya selisih tersebut dikarenakan banyaknya warga Desa Trenggulunan mencari nafkah di luar wilayah desa. Agar dapat mendiskripsikan lebih lengkap tentang informasi keadaan kependudukan di Desa Trenggulunan dilakukan identifikasi jumlah penduduk dengan menitik beratkan pada klasifikasi usia dan jenis kelamin. Sehingga akan diperoleh gambaran tentang kependudukan desa Trenggulunan yang lebih komprehensif.

Tingginya Angka Illegal Logging Hijau terhampar, menghasilkan udara segar berlantaikan tanah gembur penghasil kehidupan, satwa liar bagian dari pelengkap keindahan alam, itulah hutan yang 
mengajarkan banyak hal, mengajarkan tentang bahasa kehidupan, seperti hutan yang ada di Bojonegoro secara geografis kabupaten Bojonegoro tidak berbatasan dengan wilayah Pantai melainkan berbatasan langsung dengan beberapa wilayah kabupaten lainya di Jawa Timur, Luas kabupaten Bojonegoro Seluas $230.706 \mathrm{Ha}$, dengan jumlah penduduk sebesar 1.176.386 Jiwa merupakan wilayah dari propinsi Jawa Timur yang terletak di bagian barat jawa timur. Dari wilayah seluas itu, sebanyak 40,15\% merupakan hutan Negara, sedangkan yang di gunakan untuk perkebunan dan sawah tercatat hanya sekitar 32,58 persen.

Sebagai daerah yang beriklim tropis, kabupaten ini sangat berpotensi untuk digunakan sebagai lahan pertanian, tetapi hasil dari pertanian itu sendiri tidak bisa diandalkan untuk memenuhi kebutuhan ekonomi, karena masih sangat tergantung pada faktor musim dan cuaca. Karena dari faktor tersebut masyarakat berusaha mencari penghasilan lain untuk memenuhi kebutuhan ekonomi, salah satunya adalah dengan melakukan illegal logging.

Sebenarnya masalah ilegal logging di kabupaten Bojonegoro sudah menjadi issue yang sudah lama diperbincangkan oleh kalangan masyarakat dan media sosial, faktor tersebut juga di pengaruhi oleh sedikitnya tenaga pengawas hutan yang tidak sebanding dengan luas hutan yang di jaga, setiap 1 polisi hutan harus mengawasi hutan seluas 100 hektar, dari hal ini sangat memungkinkan terjadinya illegal logging di desa Trenggulunan. Sulit terungkapnya kasus ini karena sulitnya mencari data yang valid dan adanya kerjasama antara pelaku illegal logging dengan pihak tertentu.

Contohnya illegal logging yang terjadi di desa Trenggulunan kecamatan Ngasem kabupaten Bojonegoro. Praktek illegal longing di daerah ini sudah terjadi cukup lama, karena menurut penuturan masyarakat telah terjadi karena adanya kerja sama antara pihak-pihak tertentu dengan para pelaku. Faktor terbesar adanya illegal logging di daerah ini di karenakan SDM yang kurang memiliki kompetensi dalam persaingan hidup yang terjadi di masa sekarang ini, dalam prakteknya pemerintah sudah berusaha menindak tegas tentang larangan pengambilan kayu tanpa izin dengan mengeluarkan beberapa peraturan misalnya pencurian berat di hukum dengan hukuman 10 tahun penjara dengan denda setinggi -tinginya, hal ini tertera (UU RI No.41 Th. 1999 Pasal 78 Ayat 5).

Hampir setiap pagi masyarakat membawa potongan kayu hasil jarahan dengan menggunakan sepeda motor untuk, menurut
Pak Joko salah satu saksi terjadinya illegal logging di desa Trenggulungan para pekerja mengangkut kayu secara berkelompok dan itu terlihat ketika mereka kembali dari hutan, 4 sampai 5 orang mengangkut secara beriringan hal ini dilakukan untuk saling menjaga keamanan satu sama lain, dapat dilihat dengan sangat jelas bahwa pelaku illegal loging sudah sangat berpengalaman dan tahu kondisi lapangan. Pelaku illegal loging dimata masyrakat mempunyai satu tingkat perekonomian yang lebih baik dari masyrakat pada umumnya, karena harga kayu khususnya kayu jati mempunyai nilai yang mahal di pasaran.

Menurut keterangan polisi hutan bahwa kegiatan illegal loging di desa ini sangat kecil, tapi hal ini sangat berbeda sekali dengan keterangan yang di berikan oleh masyarakat setempat, para penjarah kayu di desa ini masih terbilang kasus yang cukup serius, terbukti dengan di tangkapnya 2 masyarakat setempat pelaku iilegal loging pada tahun 2015, 2 orang ini masuk tahanan karena melakukan penebangan kayu tanpa ada surat izin dari pemerintah dan hal ini di lakukan sudah bertahun-tahun.

\section{Relasi Kuasa Tengkulak}

Pengolahan hasil pertanian desa Trenggulunan terbagi menjadi dua yaitu dikonsumsi sendiri dan dijual. Hasil pertanian yang dijual antara lain padi, jagung, ketela pohon, cabai, tembakau, kacang hijau dan kacang tanah. Hal ini sesuai dengan hasil survey yang telah dilakukan oleh Peneliti kelompok 57 tahun 2016. Dari hasil survei terlihat bahwa seluruh hasil tani dijual kepada tengkulak. Selain ke tengkulak, hasil tani seperti kacang tanah, jagung, dan ketela pohon dijual ke pasar, padi dijual ke masyarakat sekitar.

Jika dilihat secara runtutan perjalannya dapat diketahui bahwa tengkulak, UD, pasar dan masyarakat adalah empat hal yang menjadi tempat petani dalam menjual hasil taninya. Tengkulak termasuk kelompok yang memiliki pengaruh kuat dan bersentuhan langsung dengan petani desa Trenggulunan. Mereka adalah kelompok paling utama yang menjadi sasaran petani dalam menjual hasil taninya. Pasar juga mempunyai pengaruh yang cukup kuat bagi petani desa Trenggulunan. Kelompok lain yang memiliki jumlah besar, namun kurang memiliki 20 pengaruh terhadap petani adalah agen. Seperti yang tergambarkan dalam diagram dibawah, dapat terlihat bahwa UD (Unit Dagang) mempunyai pengaruh yang sangat kecil dibandingkan dengan kelompok yang lainya. 


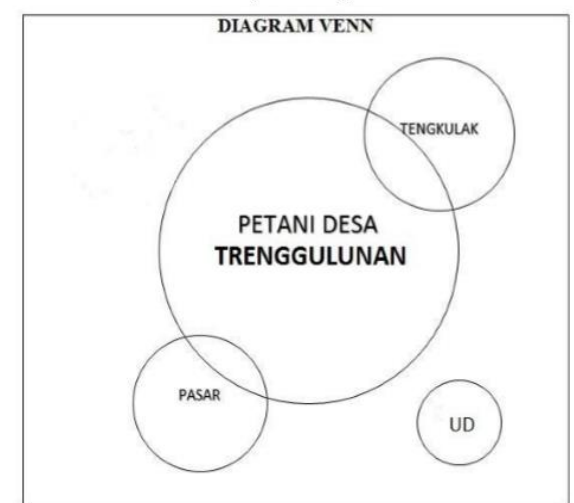

Gambar 3 Diagram Venn

Berdasarkan gambar 3 di atas, dapat disimpulkan bahwa tengkulak merupakan pihak yang paling berpengaruh terhadap petani desa Trenggulunan. Petani menjual hasil taninya dengan tidak menentukan harga jualnya. Tengkulak yang menentukan harga dari hasil tani tersebut. Dengan kata lain, petani tidak mendapatkan keuntungan yang layak dari produk yang dihasilkan dan keuntungan maksimal justru diperoleh dari tengkulak yang memanfaatkan rendahnya daya tawar petani dalam menentukan harga serta minimnya akses petani terhadap pasar, dan UD. Selain itu, para petani lebih senang menjual hasil taninya ke tengkulak karena hasil taninya lebih cepat terjual. Sedangkan jika hasil taninya di jual ke masyarakat atau pasar akan lebih sulit dan lama karena harus ada perjanjian terlebih dahulu dengan pihak yang ingin membeli. Pendapatan petani akan menjadi maksimal jika petani sendiri yang menentukan harga jual hasil panennya sebagaimana di negara Jepang. Selain itu, petani juga bisa mengolah secara kreatif hasil panennya.

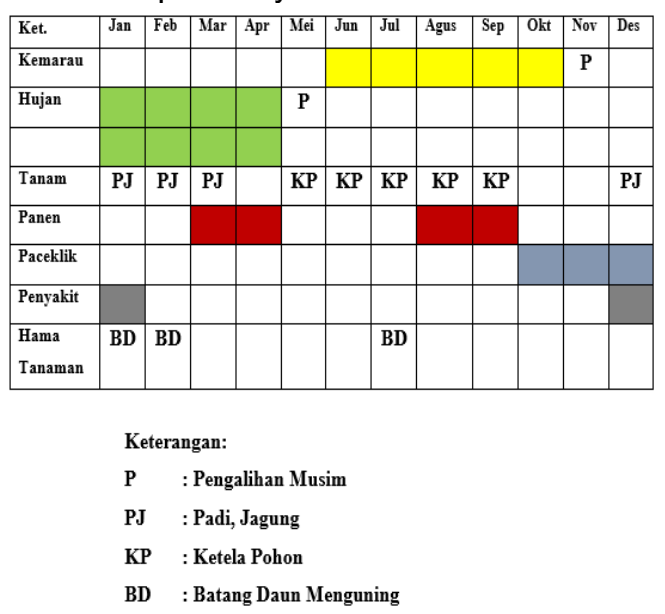

Gambar 4 : Kalender Musim
Dalam menggarap sawah, banyak masalah yang dihadapi oleh petani. Berdasarkan transect (penelusuran wilayah) masalah yang dihadapi petani yaitu sulitnya pengairan. Petani Trenggulunan sulit pengairan. Hal ini dikarenakan sulitnya air yang mengalir kesawah. Karena itu para petani hanya memanfaatkan musim hujan untuk pengairan sawahnya. Sehingga padi hanya dapat ditanam setahun sekali.

\section{Mengelola "Menyok Gendurwo" menjadi Hasil Olahan Berupa Kripik}

Krupuk singkong merupakan salah satu produk makanan ringan yang banyak digemari oleh konsumen. Rasanya agak renyah dan murahnya harga yang ditawarkan menjadikan produk tersebut sebagai alternative tepat untuk menemani waktu santai bersama rekan keluarga. Seiring dengan meningkatkannya permintaan konsumen, kini krupuk singkong mulai diinovasikan menjadi krupuk dengan berbagai varian rasa.

Varian rasa tersebut yaitu rasa original, Barbeque, balado. Special pedas, jagung dan ayam pnggang. Sejatinya produk krupuk singkong bukan barang baru bagi masyarakat namun, dengan menambahkan sedikit inovasi dalam hal rasa didalamnya bisa menjadi salah satu peluang bisnis menarik yang menjanjikan untung besar bagi pelakunya.

Berdasarkan hasil pemasaran yang Peneliti lakukan, ternyata setelah diberi berbagai varian rasa kami juga harus mengentahui berapa prosentase ketertarikan masyarakat sekitar terhadap kerupuk singkong yang kami pasarakan secara sederhana tersebut. Ternyata diketahui hamper setiap masyarakat dan instansi lokal yang kami tawarkan kerupuk simgkong lebih menunjukan minat dan apresiasi terhadap ide - ide brilian dari pengemasan sederhana, label yang cantik dan menarik sekaligus pemasaran diberbagai instansi dan masyarakat sekitar.

\section{Menata Kelembagaan}

Berkaca pada makna antara dinamika dan organisasi, keduanya memiliki makna yang berkaitan keduanya memiliki makna simbiosis mutualisme. Berasal dari arti katanya, dinamika organisasi selalu saja digambarkan dengan suatu bentuk pengorganisasian yang didalamnya terdapat beberapa individu yang saling berinteraksi sekaligus menggambarkan bahwa organisasi tersebut mulai berkembang dan mengalami kemajuan. Setiap organisasi pasti memiliki keterkaitan antara anggota yang satu dengan anggota yang lain baik dalam hal keterampilan. Sama halnya dengan dinamika organisasi yang tercipta dalam rumah produksi krupuk Merana. Dinamika yang dibangun selalu 
saja berkesinambungan atau berhubungan antara yang satu dengan yang lain. Selalu disnyalir bahwa, setiap kelompok selalu bersimbiosis mutualisme untuk mencapai tujuan yang dinginkan. tapi semuanya hambar tanpa rasa. Hidup tak selamanya indah dan jalan yang diharapkan tak selamanya lurus, begitupun dengan dinamika organisasi pembuatan kerupuk singkong asli desa Trenggulunan bojonegoro. diawal berdirinya pembuatan kerupuk singkong organisasi yang sudah dibentuk hanya bisa berjalan selama beberapa waktu saja hal tersebut dikarenakan keluh kesah para pekerja dengan fasilitas seadanya yang masih tradisional. Tapi itu tak pernah menyurutkan semangat para anggota atau pekerja, selama kurang lebih 7 tahunan mereka bekerja dengan alat seadanya. Entah kenapa tiba- tiba dipertengahan tahun rumah produksi yang biasanya selalu dibisingkan dengan riuh para pekerja saat itu juga hening tanpa suara, dan gelap gulita tak bermentari. Miris sekaligus menusuk hati, diera yang serba modern seperti saat itu alat pembuatan masih sederhana dan bahkan jauh dari jangkauan dan bantuan dari pihak setempat. Saat ini, dunia perekonomian sudah memasuki taraf pengembangan diwilayah Asia, organisasi yang redup kini oleh Peneliti tampakan lagi kepermukaan dengan tujuan membantu perekonomian masyarakat khususnya di desa Trenggulunan. Lewat reformasi ulang sturktur organisasi yang ada, pembuatan kembali kerupuk singkong serta pelatihan sekaligus penyuluhan dari pihak kecamatan kini sudah mulai ditiupkan lagi dibumi trenggulunan. Tujuan akhir dari pendampingan kami selama kurang lebih 1 bulan tak lain adalah memberdayakan masyarakat dengan basis teori yang sudah didapatkan. Dinamika organisasi saat ini masih dalam proses pembangkitan kembali dari keterpurukan yang selama ini terjadi.

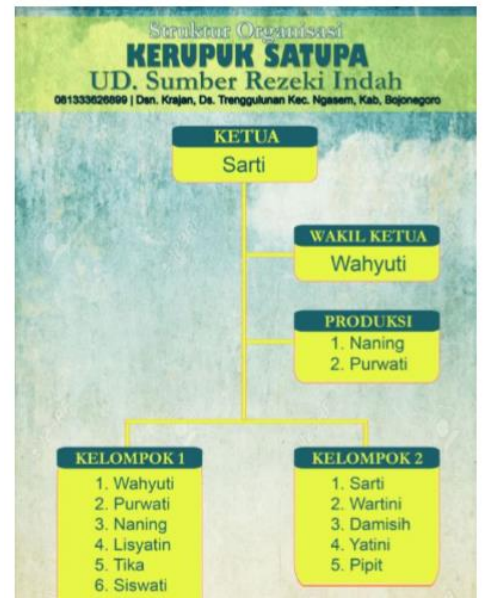

Gambar 5 : Struktur Organisasi
Struktur organisasi UD Sumber Rezeki Indah adalah hasil dari pembinaan dari pihak pemerintah. Pembinaan dari pihak kecamatan dan telah diadakan penyuluhan terhadap pembuatan krupuk menyok, kemudian dibentuk kelompok-kelompok produksi krupuk menyok. Seiring berjalannya waktu, organisasi yang sudah lama berkembang mengalami kendala yang amat dahsyat. Organisasi yang sudah tertata rapi dan dibentuk berdasarkan hasil musyawarah antara orang yang memiliki kemauan untuk bergabung dengan pembuatan krupuk merana lambat laun mencapai ujung tombak. Beberapa bulan kemudian kelompokkelompok tersebut memproduksi krupuk menyok, namun dari pihak kecamatan tidak memonitoring atau tidak memberikan feedback terhadap kegiatan produksi krupuk menyok. Kelompok-kelompok tersebut menghilang seperti ditelan bumi. Bahkan proses produksipun berada pada titik darah kemunduran. Hal tersebut tak sejalan dengan harapan yang dicita- citakan oleh ketua pengelola, semuanya hancur berkeping tak tersisa. Kelompok yang dulu dibuat serapi dan sedemokrasi mungkin kini telah berada diambang kepunahan. Para pekerja, bahan mentah dan alat yang digunakanpun juga ikut mengendor, hanya tersisa alat tua dan ketua produksi krupuk tersebut yang bertahan dan tetap strong. Sehingga hasil panen menyok tidak di produksi secara maksimal bahkan menyok hanya dibuat untuk makanan ternak. Pada tanggal 06 februari tepatnya setelah berdiskusi baik dengan ketua rumah produksi dan masyarakat yang dulunya pernah turut andil dalam pembuata kerupuk singkong, Peneliti mengajak kembali para ibu- ibu khususnya dan para masyarakat desa Trenggulunan pada umumnya untuk menghidupka kembali atau membangkitkan kembali organisasi yang dulunya pernah melambung tinggi itu. Berbagai masukan dari masyarakat yang dulu pernah ikut andil telah disepakati bersama, aksipun telah kami transfer kepada ketua dan anggota dan ilmu yang sedikit telah kami turunkan kepada ketua dan para anggota refleksi yang telah dirancang serapi mungkinpun telah kami presentasikan dihadapan mereka. Semuanya dilakukan secara bertahap dalam waktu yang tidak lama ini. Kesadaran masyarakat telah berhasil kami bangkitkan kembali untuk tetap kembali bekerja dan belajar bersama- sama dirumah produksi kerupuk merana.

\section{Strategi Pemberdayaan Pengolahan "Menyok Gendurwo"}

Mewujudkan cita-cita dari masyarakat Desa Trenggulunan menjadi Desa yang dapat 
Mengembangkan Perekonomian dengan memanfaatkan Sumber Daya Manusia (SDM). Agar menjadi masyarakat yang Kreative dan berkembang dalam bidang ekonomi maka diperlukan strategi yang tepat untuk mencapain tujuan tersebut. Agar perekonomian masyarat meningkat. Dari alasan tersebut maka perlu adanya strategi tertentu untuk meningkatkan perekonomian masyarakat, strategi yang tumbuh dari masyarakat (Suharto, 2010). Melalui pengamatan yang sudah dilakukan oleh peneliti, mata pencaharian masyarakat Desa. Trenggulunan adalah petani. Yang dapat diinovasi dari berbagai hasil pertanian yaitu ketela pohon, yang ditinjau dari tanaman yang tidak membutuhkan banyak air dan mudah untuk di tanam dan hasil panen ketela pohon yang melimpah, namun harga jual ketela pohon sangat murah sehingga perlu adanya strategi untuk meningkatkan harga jual ketela pohon yang nantinya bisa meningkatkan perekonomian masyarakat.

Hasil perbincangan Peneliti dengan masyarakat, tentang penginovasian ketela pohon menjadi sebuah kerupuk nampaknya ini bukan hal baru bagi mereka karena mereka sudah pernah mendapatkan pelatian pengarahan dari petugas setempat. Hanya saja tidak ada yang menindak lanjuti karena sistem yang dijelaskan sangat minim sehingga masyarakat tidak tahu hasil inovasi ketela pohon akan di perjual belikan kemana.

Di samping karena faktor keterbatasan alat, kurangnya antusias warga, dan kurangnya motivasi dari pejabat setempat, karena peran pemerintah mempengaruhi kebijakan (Sugandi, 2009). Sehingga mereka menyarankan kita untuk bertemu dengan Ibu Sarti satu-satunya orang yang masih memproduksi kerupuk. setelah wawancara dengan ibu Sarti sebagai satu-satunya pengusaha krupuk menyok di desa Trenggulunan, akhirnya kami mencoba meningkatkan nilai jual dari krupuk menyok ini. Dimulai dengan mengetahui proses pembuatan sampai penjualan. Peneliti turun langsung ke sawah mulai dari mencari ketela pohon dan mencabut ketela pohon serta mengikuti proses pembuatan krupuk dari awal hingga menjadi krupuk yang digoreng dan siap makan. Kami melakukan inovasi rasa dengan memberikan berbagai rasa pada kerupuk menyok, memberikan pengemasan yang lebih menarik dan memberitahu tentang pendistribusian kerupuk menyok sehingga harga jual keripuk menyok menjadi lebih mahal dan masyarakat menjadi lebih antusias untuk memproduksi kerupuk menyok.

Peneliti mengadakan sosialisasi tentang peningkatan daya jual suatu komoditi yang dihasilkan oleh warga dari pertanian yaitu tanaman ketela pohon. Ketela pohon awalnya hanya langsung dijual langsung yang pastinya dibeli dengan harga murah. Meskipun tak jarang ada warga yang mengolahnya menjadi kerupuk menyok akan tetapi hal tersebut kurang bisa meningkatkan harga jual dari komoditi ketela pohon karena kerupuk menyok hanya dijual dalam keadaan mentah (belum digoreng). Dari alasan ini lah peneliti mencoba menemukan solusi bagamana agar tanaman ketela pohon bisa ditingkatkan daya jualnya. Bersama masyarakat peneliti memberikan motivasi dengan cara memberikan variasi rasa pada kerupuk menyok yang bisa menaikkan harga jual di pasaran. Peneliti mengadakan pelatihan dan praktik bersama masyarakat dalam pengolahan kerupuk menyok dan pengemasannya yang lebelnya diberi stiker produk krupuk. Setelah adanya pelatihan mengenai pemberian variasi rasa dan pengemasan krupuk menyok diharapkan masyarakat desa Trenggulunan mempunyai pendapatan tambahan dan tidak hanya bergantung pada hasil tanam.

\section{SIMPULAN DAN SARAN}

Trenggulunan merupakan salah satu desa di kecamatan Ngasem bagian Selatan yang memiliki banyak potensi apabila didukung oleh sumber daya alam yang baik. Potensipotensi tersebut antara lain dalam bidang pertanian, pendidikan, dan keagamaan. Potensi pertanian yang paling terlihat di desa Trenggulunan terletak pada banyaknya lahan persawahan yang bisa digunakan warga sebagai tempat bercocok tanam. Jika berbicara tentang potensi pendidikan memang pendidikan warga desa Trenggulunan rata-rata hanya tamat SD, tetapi ilmu mereka tentang pertanian sudah cukup tinggi. Sedangkan mengenai potensi keagamaan, warganya memiliki keyakinan yang beragam, tetapi sikap toleransinya sangat tinggi. Meskipun banyak potensi yang dimiliki desa Trenggulunan, tetapi terdapat satu permasalahan inti yaitu rendahnya pendapatan masyarakat.

Rendahnya pendapatan masyarakat ini karena hasil tani yang menjadi sumber pemasukan utama desa Trenggulunan dijual kepada tengkulak dengan harga yang murah. Untuk meningkatkan harga jual hasil tani, maka peneliti mencoba memberikan memotivasi masyarakat untuk mengolah salah satu hasil tani desa Trenggulunan yakni Menyok atau ketela pohon.

Kebiasaan mereka menggantungkan pendapatan pada sektor praktis, seperti mengambil jati milik perhutani, merantau dan nikah muda sebagai pelarian. Usaha mereka untuk hidup berdampingan dengan alam dan 
dapat mengolah hasil panen secara maksimal serta keseluruhan belum dapat terwujud. Hingga hasil panen menyok yang diolah dengan alasan hasil produksi terbanyak. Sentuhan kecil ini dimulai dari tahapan-tahapan menggali data, proses FGD (focus grup discussion), pembuatan strategi, hingga pada tahap pengemasan, dan sekaligus pemasaran, bukan hanya sekedar itu namun pada tahap perijinan dan kelembagaan juga kita dampingi sebagai bentuk bagian dari unsur Sustainability sebuah proses pemberdayaan kepada masyarakat. Pada tahap pemasaran peneliti mencoba memperkenalan kepada dinas-dinas, seperti PPL Desa Trenggulunan, Kecamatan, Puskesmas, Polres Kecamatan Ngasem, Koramil, Perhutani dan Para Mantri Penjaga Pos Pemerikasaan, dan juga Dinas Kesehatan Kabupaten Bojonegoro mendapat respon yang sangat positif.

Memang mereka mengakui, salah satu faktor krusial yang dihadapi oleh masayarakat Trenggulunan adalah problem ekonomi, didukung dengan kehidupan mereka yang meminta untuk hidup hedonis dan pragmatis tanpa diimbangi dengan etos kerja yang mumpuni. Sehingga sejumlah kriminalitas seperti Illegal Logging terjadi. Para aparat desa juga sangat penting akan peran dalam proses penciptaan desa yang swasembada.

Pada saat ini fokus aparat desa masih terbatas pada pembangunan secara fisik dan belum menyentuh pada pembangunan sumber daya manusianya. Padahal kualitas sebuah desa bukan hanya diukur pada bentuk fisiknya namun juga kualitas masyarakat yang menempati pada desa tersebut. Sebuah ironi yang sangat tepat jikalau kepala Negara atau presiden Negara Indonesia menyarankan sentra ekonomi melalui Desa, pemberian wewenang itu turun untuk membuat undangundang Desa, dalam aturan tersebut Desa mempunyai hak prerogratif dalam mengembangkan potensinya.

Manifestasinya dengan pemberian intensif berupa peningkatan APBDes yang mencapai 1,2 Miliar. Hal ini selaras dengan keinginan bersama bahwa dapat membuat Desa Trenggulunan berdaya dengan kekuatan lokal dapat memecahkan masalah dan mengembangkan semua potensi yang dimiliki oleh Desa Trenggulunan. Koordinasi pemimpinan dengan masyarakat sangatlah dibutuhkan, karena dalam proses pembangunan desa yang swasembada tidak boleh melangkah sendiri-sendiri. Sebuah system yang singkron diharap dapat mewujudkan cita-cita visi misi Desa Trenggulunan, yang unggul dan produktif.

\section{UCAPAN TERIMA KASIH}

Peneliti mengucapkan banyak terimakasih kepada keluarga besar Desa Trenggulunan sebagai tempat belajar dan belajar penghidupan. Peneliti juga mengucapkan terimakih pada almamater Universitas Gadjah Mada dan pemberi beasiswa Lembaga Pengelola Dana Pendidikan (LPDP) yang telah memberi kesempatan peneliti untuk menimba ilmu higga titik ini. Kedua orangtua yang selalu mendukung saya karya ini saya persembahkan untuk kalian.

\section{DAFTAR RUJUKAN}

Afandi, A. dkk. (2014). Modul Participatory Action Research. LPPM UIN Sunan Ampel.

Afandi, A. dkk. (2016). Panduan Penyelenggaraan Kuliah Kerja Nyata (KKN) Transformatif dengan MetodologiParticipatory Action Research (PAR).

Midgley, J. (2013). Social Development: Theory and Practice, 1st edition. SAGE Publishing.

Rudito, Bambang \& Famiola, M. (2013). Social Mapping. Rekayasa Sains.

Soetomo. (2015). Masalah Sosial dan Upaya Pemecahannya. Pustaka Pelajar.

Soetomo. (2018). Masalah Sosial Pembangunan Sosial dan Kesejahteraan. Pustaka Pelajar.

Suharto, E. (2010). Membangun Masyarakat Membangun Rakyat, (Kajian Strategis Pembangunan Kesejahteraan Sosial Dan Pekerjaan Sosial). PT Refika Aditama.

Yuliana, R. (2012). Peran Komunikasi Dalam Organisasi. Journal of STIE Semarang, 4(3). 